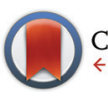

CrossMark \&lick for updates

Cite this: Polym. Chem., 2015, 6 , 3024

Received 5th February 2015,

Accepted 2nd March 2015

DOI: 10.1039/c5py00188a

www.rsc.org/polymers

\title{
Phosphonated furan-functionalized poly(ethylene oxide)s using orthogonal click chemistries: synthesis and Diels-Alder reactivity $\dagger$
}

\author{
Thi Thanh Thuy N'Guyen, Guillaume Contrel, Véronique Montembault, * \\ Gilles Dujardin and Laurent Fontaine*
}

\begin{abstract}
The synthesis and the reactivity in Diels-Alder and retro Diels-Alder (DA/rDA) reactions of a series of novel phosphonated furan-functionalized PEO monomethyl ethers were investigated. Dimethylphosphonate-terminated furan-functionalized PEO monomethyl ethers and their phosphonic acid-terminated derivatives have been successfully prepared by using a combination of click copper-catalyzed 1,3dipolar cycloaddition and Kabachnik-Fields reactions. Influence of both the substitution pattern of the furan ring and the solvent onto the DA/rDA process were investigated. It was found that the 3-substituted furan is the more reactive and that water facilitates both the DA and the rDA reactions, while maintaining the polymeric structure intact. The results demonstrate the potential of such structures for dynamic covalent applications and controlled drug delivery systems such as thermoreversible linkage of biological entities onto metallic nanoparticles.
\end{abstract}

\section{Introduction}

The Diels-Alder (DA) reaction is a well-known thermoreversible $[4+2]$ cycloaddition reaction between diene and alkene (dienophiles) derivatives. ${ }^{1,2}$ Because of its thermal reversibility, in addition to high yields and superior selectivity under mild (aqueous) conditions, this cycloaddition reaction is one of the most attractive members of the click chemistry family. ${ }^{3-7}$ DA reactions involving furan as a diene to form oxanorbornenes have attracted much attention in polymer chemistry, particularly in providing new materials and products, ${ }^{8-15}$ including bioconjugates. ${ }^{16-19}$ Recently, the reversible nature of the DA reaction has been exploited for the dynamic covalent synthesis of organic materials. ${ }^{20,21}$ We have relied on this methodology to prepare novel functional iron oxide magnetic nanoparticles (IONPs) that show unprecedented hyperthermia-induced drug release by magnetically stimulated retro Diels-Alder (rDA) process. ${ }^{22}$ Our strategy is based on a new versatile multifunctional ligand incorporating a phosphonic acid group, which strongly binds onto the iron oxide surface of the IONPs, and two orthogonal clickable (alkyne and furan) groups. The

Institut des Molécules et Matériaux du Mans (IMMM), Equipe Méthodologies et Synthèse, UMR CNRS 6283, Université du Maine, Avenue Olivier Messiaen, 72085 Le Mans Cedex 9, France. E-mail: veronique.montembault@univ-lemans.fr,

laurent.fontaine@univ-lemans.fr; Fax: +33 (0)243 8337 54;

Tel: $+33(0) 243833330$

$\dagger$ Electronic supplementary information (ESI) available: Detailed experimental procedures and NMR spectra. See DOI: 10.1039/c5py00188a alkyne moiety is used for installing via copper-catalyzed azidealkyne cycloaddition (CuAAC) an azido-end-functionalized hydrophilic poly(ethylene oxide) (PEO) that affords waterdispersibility and stability, anti-fouling, and biocompatibility. The furan ring acts as a thermoreversible linker for a biologically active molecule via thermally reversible DA chemistry (Scheme 1). We have demonstrated that upon alternating magnetic field (AMF) exposure, sufficient local energy is brought in close proximity of the cycloadduct to initiate the rDA reaction without the need for heating the solution at the elevated temperature usually required for such a process. ${ }^{22}$ Those functional IONPs have thus the potential to improve hyperthermia therapies by expanding the range of polymers and drugs that can be used.

Herein, we report on the synthesis and reactivity in DA/rDA processes of a series of new phosphonated furan-functionalized PEO monomethyl ethers that are potential candidates for a wide range of uses, including stabilization and dispersion of

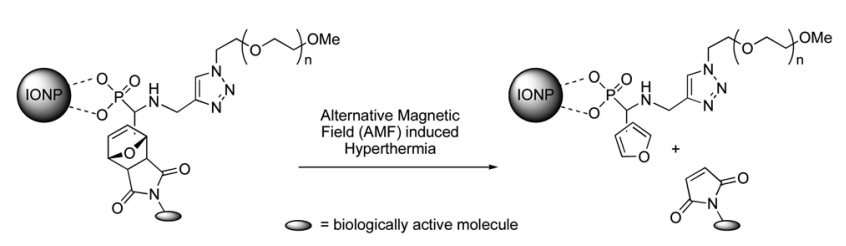

Scheme 1 The concept of magnetically stimulated rDA reaction using IONPs. 


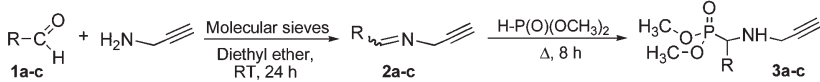

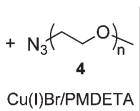

$$
\begin{aligned}
& \text { DMF, RT, } 24 \mathrm{~h}
\end{aligned}
$$

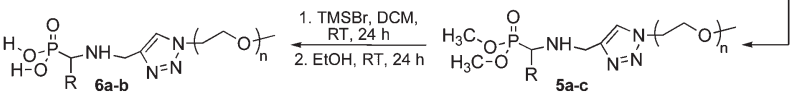

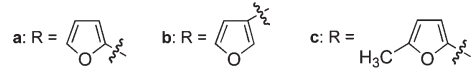

Scheme 2 Synthesis of phosphonated furan-functionalized PEO monomethyl ethers.

metallic nanoparticles. In order to study the influence of the furan substitution pattern, we first synthesized dimethylphosphonate-terminated furan-functionalized PEO monomethyl ethers $\mathbf{5 a - c}$ and their phosphonic acid-terminated homologues $\mathbf{6 a - b}$ according to our reported procedure (Scheme 2) 22,23 combining the click CuAAC ${ }^{3}$ and the Kabachnik-Fields ${ }^{24-27}$ reaction that is rarely utilized in polymer chemistry. ${ }^{23,28-32}$ Next we looked into the role of the furan substitution position onto the DA/rDA reactivity of the prepared furan-functionalized phosphonated PEOs by using $\mathrm{N}$-methylmaleimide as a model dienophile.

\section{Experimental}

\section{Materials}

Dimethylphosphonate-terminated furan-functionalized poly(ethylene oxide) (PEO) monomethyl ethers 5a-c and their phosphonic acid-terminated homologues $\mathbf{6 a - b}$ were synthesized according to the literature ${ }^{22,23}$ and the whole procedure as well as the characterization are included in the ESI. $\dagger$ All other chemicals were purchased from commercial sources and used without further purification.

\section{General characterization}

Nuclear magnetic resonance (NMR) spectra were recorded on a Bruker Avance 400 spectrometer operating at $400.16 \mathrm{MHz}$ for ${ }^{1} \mathrm{H}, 100.62 \mathrm{MHz}$ for ${ }^{13} \mathrm{C}$, and $161.96 \mathrm{MHz}$ for ${ }^{31} \mathrm{P}$ using either deuterated chloroform $\left(\mathrm{CDCl}_{3}\right)$, deuterated dimethyl sulfoxide (DMSO- $\left.\mathrm{d}_{6}\right)$, deuterium oxide $\left(\mathrm{D}_{2} \mathrm{O}\right)$ or deuterated 1,1,2,2-tetrachloroethane $\left(\mathrm{TCE}-\mathrm{d}_{2}\right)$ as the solvent. ${ }^{31} \mathrm{P}$ NMR spectra were proton decoupled. Diastereoisomers ratios were calculated from the peak integration area of a quantitative ${ }^{1} \mathrm{H}$ decoupled ${ }^{31} \mathrm{P}$ NMR spectrum acquired by a $1 \mathrm{D}$ sequence with inverse gated coupling (zgig) and a relaxation delay $D_{1}=30 \mathrm{~s} .{ }^{1} \mathrm{H}$ and ${ }^{13} \mathrm{C}$ NMR spectra were referenced to tetramethylsilane signals while ${ }^{31} \mathrm{P}$ NMR chemical shifts were referenced to $85 \%$ phosphoric acid as an external reference, with positive shift values downfield from the reference. Coupling constants and chemical shifts are reported in hertz and in parts per million (ppm), respectively. Fourier transform infra-red (FT-IR) spectra were recorded using a Nicolet avatar 370 DTGS spectrometer in transmittance mode. High resolution mass spectra (HR-MS) were recorded on a Waters-Micromass ${ }^{\circledR}$ GCT Premier $^{\mathrm{TM}}$ (GC, $\mathrm{CI}+$, methane) using a HP $6890 \mathrm{GC}$ apparatus equipped with a chromatographic column of $25 \mathrm{~m}$, diameter $250 \mu \mathrm{m}$, thickness $0.25 \mu \mathrm{m}$. The sample was warmed at a temperature of $40^{\circ} \mathrm{C}$ for $5 \mathrm{~min}$ and then further heated at a heating rate of $10^{\circ} \mathrm{C} \mathrm{min}^{-1}$ up to $220^{\circ} \mathrm{C}$.

\section{General procedure for the Diels-Alder reaction between dimethylphosphonate-terminated furan-functionalized PEO monomethyl ethers 5a-c or phosphonic acid-terminated furan-functionalized PEO monomethyl ether $6 \mathrm{~b}$ and $N$-methylmaleimide model compound}

The following protocol was used for reactions carried out in deuterated chloroform $\left(\mathrm{CDCl}_{3}\right)$ reported in Table 1 . Dimethylphosphonate-terminated furan-functionalized PEO derivatives 5a-b $(0.7 \mathrm{~g} ; 0.315 \mathrm{mmol})$ and the desired quantity of $N$-methylmaleimide $(0.315,1.575$ or $6.3 \mathrm{mmol} ; 1,5$ or 20 equivalents) were introduced in a $10 \mathrm{~mL}$ round-bottom flask equipped with a magnetic stirrer and a reflux condenser. The reaction mixture was subsequently dissolved in $3 \mathrm{~mL}$ of $\mathrm{CDCl}_{3}$. When a homogeneous solution was obtained, the $10 \mathrm{~mL}$ round-bottom flask was immersed in an oil bath preset at $40{ }^{\circ} \mathrm{C}$ to allow the reaction to proceed (initial reaction time, $t=0$ ). Samples were taken out during the reaction to monitor the conversion of the Diels-Alder (DA) reaction by ${ }^{1} \mathrm{H}$ NMR spectroscopy by comparing the peaks areas of the bridgehead protons of the oxanorbornene cycloadduct at $\delta=5.13-5.39 \mathrm{ppm}$ and the methylene protons linked to the triazole ring at $\delta=4.52 \mathrm{ppm}$. For the DA reactions carried out in a NMR tube in situ (Fig. 1, 2 \& Table 2), the following formulations were used: $5 \mathbf{b}(0.1 \mathrm{~g} ; 0.045 \mathrm{mmol})$, $N$-methylmaleimide $(0.9 \mathrm{mmol})$ and deuterated solvent: $\mathrm{CDCl}_{3}$, water $\left(\mathrm{D}_{2} \mathrm{O}\right)$ or dimethyl sulfoxide $\left(\right.$ DMSO- $\left._{6}\right)(0.4 \mathrm{~mL})$. The NMR tube was immersed in an oil bath preset at 25 or $40{ }^{\circ} \mathrm{C}$ to allow the reaction to proceed (initial reaction time, $t=0$ ). NMR spectra were carried out periodically to monitor the conversion of the DA reaction by ${ }^{1} \mathrm{H}$ NMR spectroscopy. The DA reaction

Table 1 Influence of the furan position on the DA reaction between $5 a-c$ and $N$-methylmaleimide at $40^{\circ} \mathrm{C}$ during 5 days

\begin{tabular}{|c|c|c|c|c|}
\hline Run & $\begin{array}{l}\text { Dimethylphosphonate- } \\
\text { terminated PEO }\end{array}$ & Solvent & $\begin{array}{l}{[N \text {-Methyl- }} \\
\text { maleimide }]_{0} / \\
{[\mathbf{5 a - c}]_{0}}\end{array}$ & $\begin{array}{l}\text { Conv. }^{a} \\
(\%)\end{array}$ \\
\hline 1 & $5 a$ & $\mathrm{CDCl}_{3}$ & 1 & 0 \\
\hline 2 & $5 b$ & $\mathrm{CDCl}_{3}$ & 1 & 10 \\
\hline 3 & $5 \mathbf{a}$ & $\mathrm{CDCl}_{3}$ & 5 & 0 \\
\hline 4 & $5 b$ & $\mathrm{CDCl}_{3}$ & 5 & 13 \\
\hline 5 & $5 a$ & $\mathrm{CDCl}_{3}$ & 20 & 0 \\
\hline 6 & $5 b$ & $\mathrm{CDCl}_{3}$ & 20 & 82 \\
\hline 7 & $5 \mathbf{a}$ & $\mathrm{DMF}$ & 20 & 18 \\
\hline 8 & $5 b$ & DMF & 20 & 98 \\
\hline 9 & $5 c$ & DMF & 20 & 50 \\
\hline
\end{tabular}

${ }^{a}$ Determined by ${ }^{1} \mathrm{H}$ NMR spectroscopy by comparing the peak areas of the $\mathrm{CH}-\mathrm{O}$ groups of oxanorbornene at $\delta=5.13-5.39 \mathrm{ppm}$ and the methylene protons of the PEO in $\alpha$ of the triazole ring at $\delta=4.52 \mathrm{ppm}$. 

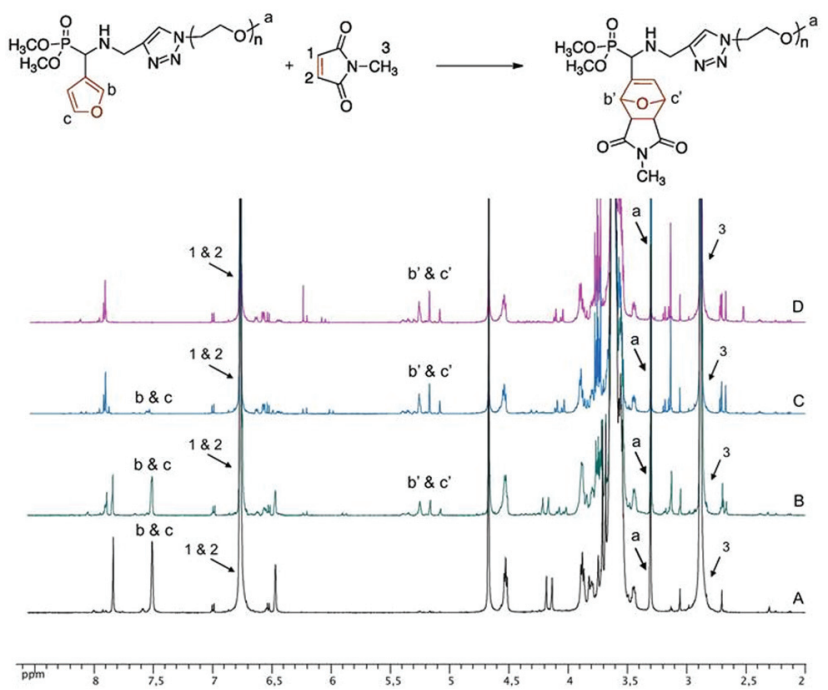

Fig. 1 Overlay of ${ }^{1} \mathrm{H}$ NMR spectra of the reaction mixture of $5 \mathrm{~b}$ and $\mathrm{N}$-methylmaleimide for a $[\mathrm{N}$-methylmaleimide]/[5b] molar ratio of 20 in $\mathrm{D}_{2} \mathrm{O}$ at $40{ }^{\circ} \mathrm{C}$ recorded for a reaction time of (A) $t=0$, (B) $t=3 \mathrm{~h}$, (C) $t=$ 1 day and (D) $t=3$ days.

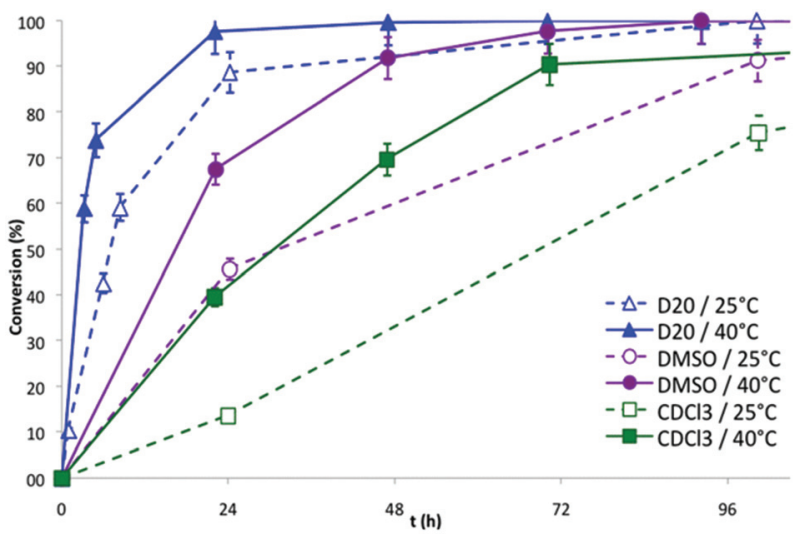

Fig. 2 Conversion of the DA reaction between $5 \mathrm{~b}$ and $\mathrm{N}$-methylmaleimide in different solvents at $25^{\circ} \mathrm{C}$ and $40^{\circ} \mathrm{C}$ versus time.

Table 2 Conversion of the DA reaction between furan-functionalized PEO $5 \mathrm{~b}$ or $6 \mathrm{~b}$ and $N$-methylmaleimide for a $[N$-methylmaleimide]/[5b or $6 \mathrm{~b}]$ molar ratio of 20 after a reaction time of $24 \mathrm{~h}$

\begin{tabular}{lllll}
\hline Run & $\begin{array}{l}\text { Furan-functionalized } \\
\text { PEO }\end{array}$ & Solvent & $\begin{array}{l}\text { Temperature } \\
\left({ }^{\circ} \mathrm{C}\right)\end{array}$ & $\begin{array}{l}\text { Conv. }^{a} \\
(\%)\end{array}$ \\
\hline 1 & $\mathbf{5 b}$ & $\mathrm{CDCl}_{3}$ & 25 & 14 \\
2 & $\mathbf{5 b}$ & $\mathrm{DMSO}^{-} \mathrm{d}_{6}$ & 25 & 46 \\
3 & $\mathbf{5 b}$ & $\mathrm{D}_{2} \mathrm{O}$ & 25 & 89 \\
4 & $\mathbf{6 b}$ & $\mathrm{D}_{2} \mathrm{O}$ & 25 & 47 \\
5 & $\mathbf{5 b}$ & $\mathrm{CDCl}_{3}$ & 40 & 59 \\
6 & $\mathbf{5 b}$ & $\mathrm{DMSO}_{6}$ & 40 & 68 \\
7 & $\mathbf{5 b}$ & $\mathrm{D}_{2} \mathrm{O}$ & 40 & 98 \\
8 & $\mathbf{6 b}$ & $\mathrm{D}_{2} \mathrm{O}$ & 40 & 90
\end{tabular}

${ }^{a}$ Determined by ${ }^{1} \mathrm{H}$ NMR spectroscopy by comparing the peak areas of the $\mathrm{CH}-\mathrm{O}$ groups in the furan ring at $\delta=7.40-7.60 \mathrm{ppm}$ and the $\mathrm{CH}_{3}$ end-group of PEO at $\delta=3.38 \mathrm{ppm}$. from the phosphonic acid-terminated furan-functionalized PEO monomethyl ether $\mathbf{6 b}$ was carried out in a NMR tube in situ using the following formulation: $6 \mathbf{b}(0.045 \mathrm{mmol})$, $N$-methylmaleimide $(0.9 \mathrm{mmol})$ and $\mathrm{D}_{2} \mathrm{O}(0.4 \mathrm{~mL})$.

For reactions carried out in non-deuterated solvent $\mathrm{N}, \mathrm{N}$-dimethylformamide (DMF) reported in Table 1, dimethylphosphonate-terminated furan-functionalized PEO derivatives 5a-c $(0.2 \mathrm{~g} ; 0.09 \mathrm{mmol})$ and $N$-methylmaleimide $(1.8 \mathrm{mmol} ; 20$ equivalents) were introduced in a $25 \mathrm{~mL}$ round-bottom flask equipped with a magnetic stirrer and a reflux condenser. The reaction mixture was subsequently dissolved in $5 \mathrm{~mL}$ of DMF. When a homogeneous solution was obtained, the $25 \mathrm{~mL}$ round-bottom flask was immersed in an oil bath preset at $40{ }^{\circ} \mathrm{C}$ to allow the reaction to proceed (initial reaction time, $t=0$ ). At the end of the reaction, the resulting mixture was concentrated under vacuum and precipitated into diethyl ether. The yellow powder was subsequently dried under vacuum at ambient temperature. Conversions were determined from ${ }^{1} \mathrm{H}$ NMR spectra by comparing the peaks areas of the bridgehead protons of the oxanorbornene cycloadduct at $\delta=5.13-$ $5.39 \mathrm{ppm}$ and the methylene protons linked to the triazole ring at $\delta=4.52 \mathrm{ppm}$.

Dimethylphosphonate-terminated oxanorbornene-functionalized PEO monomethyl ether 7a. [N-Methylmaleimide]/[5a] = 20 (Table 1, run 7); conv.: 18\%. ${ }^{1} \mathrm{H}$ NMR $\left(\mathrm{CDCl}_{3}, 400 \mathrm{MHz}\right)$, $\delta(\mathrm{ppm}): 7.62(\mathrm{~s}, 1 \mathrm{H}$, triazole $) ; 6.28(\mathrm{~d}, J=6.22 \mathrm{~Hz}, 2 \mathrm{H}, \mathrm{C} H=\mathrm{C})$; $5.23(\mathrm{~m}, 1 \mathrm{H}, \mathrm{CH}-\mathrm{O}) ; 4.52\left(\mathrm{~m}, 2 \mathrm{H}, \mathrm{N}_{\text {triazole }}-\mathrm{CH}_{2}-\mathrm{CH}_{2}-\mathrm{O}\right) ; 4.23$ (d, $1 \mathrm{H}, J=21.43 \mathrm{~Hz}, \mathrm{CHP}) ; 3.94\left(\mathrm{~m}, 2 \mathrm{H}, \mathrm{N}_{\text {triazole }}-\mathrm{CH}_{2}-\mathrm{CH}_{2}-\mathrm{O}\right)$; 3.87 (m, 6H, P(O)O-CH $\mathrm{CH}_{3}$; 3.78-3.51 (m, $\left.172 \mathrm{H}, \mathrm{CH}_{2}-\mathrm{CH}_{2}-\mathrm{O}\right)$; $3.46\left(\mathrm{t}, J=4.60 \mathrm{~Hz}, 2 \mathrm{H}, \mathrm{NH}-\mathrm{CH}_{2}\right) ; 3.38\left(\mathrm{~s}, 3 \mathrm{H}, \mathrm{O}-\mathrm{CH}_{3}\right) ; 3.21(\mathrm{~m}$, $2 \mathrm{H}, \mathrm{CHC}=\mathrm{O}) ; 2.98\left(\mathrm{~s}, 3 \mathrm{H}, \mathrm{CH}_{3}-\mathrm{N}\right) ; 2.32(\mathrm{~s}, 1 \mathrm{H}, \mathrm{NH}) .{ }^{31} \mathrm{P}$ NMR $\left(\mathrm{CDCl}_{3}, 161.96 \mathrm{MHz}\right), \delta$ (ppm): 27.69; 26.72; 25.48; 24.37.

Dimethylphosphonate-terminated oxanorbornene-functionalized PEO monomethyl ether $\mathbf{7 b}$. [N-Methylmaleimide]/[5b] = 20 (Table 1, run 8); conv.: 98\%. ${ }^{1} \mathrm{H}$ NMR $\left(\mathrm{CDCl}_{3}, 400 \mathrm{MHz}\right)$, $\delta(\mathrm{ppm}): 7.66$ (s, $1 \mathrm{H}$, triazole); $6.46(\mathrm{~d}, J=6.17 \mathrm{~Hz}, 1 \mathrm{H}, \mathrm{C} H=\mathrm{C})$; $5.23(\mathrm{~m}, 2 \mathrm{H}, \mathrm{CH}-\mathrm{O}) ; 4.53\left(\mathrm{t}, J=4.18 \mathrm{~Hz}, 2 \mathrm{H}, \mathrm{N}_{\text {triazole }}-\mathrm{CH}_{2^{-}}\right.$ $\left.\mathrm{CH}_{2}-\mathrm{O}\right) ; 4.04(\mathrm{~m}, 1 \mathrm{H}, \mathrm{CHP}) ; 3.95\left(\mathrm{t}, J=5.64 \mathrm{~Hz}, 2 \mathrm{H}, \mathrm{N}_{\text {triazole }}{ }^{-}\right.$ $\left.\mathrm{CH}_{2}-\mathrm{CH}_{2}-\mathrm{O}\right) ; 3.86\left(\mathrm{~m}, 6 \mathrm{H}, \mathrm{P}(\mathrm{O}) \mathrm{O}-\mathrm{CH}_{3}\right) ; 3.78-3.52(\mathrm{~m}, 172 \mathrm{H}$, $\mathrm{CH}_{2}-\mathrm{CH}_{2}-\mathrm{O}$ ); 3.46 (t, $\left.J=4.87 \mathrm{~Hz}, 2 \mathrm{H}, \mathrm{NH}-\mathrm{CH}_{2}\right) ; 3.38(\mathrm{~s}, 3 \mathrm{H}$, $\left.\mathrm{O}-\mathrm{CH}_{3}\right) ; 3.26(\mathrm{~d}, J=6.95 \mathrm{~Hz}, 1 \mathrm{H}, \mathrm{CHC}=\mathrm{O}) ; 3.22(\mathrm{~d}, J=5.95 \mathrm{~Hz}$, $1 \mathrm{H}, \mathrm{CHC}=\mathrm{O}) ; 2.97\left(\mathrm{~s}, 3 \mathrm{H}, \mathrm{CH}_{3}-\mathrm{N}\right) ; 2.52(\mathrm{~s}, 1 \mathrm{H}, \mathrm{NH}) .{ }^{13} \mathrm{C} \mathrm{NMR}$ $\left(\mathrm{CDCl}_{3}, 100.62 \mathrm{MHz}\right), \delta(\mathrm{ppm}): 176.37(C=\mathrm{O}) ; 146.80(C=\mathrm{CH})$; $145.13\left(C=\mathrm{C}-\mathrm{N}_{\text {triazole }}\right) ; 133.57(\mathrm{CH}-\mathrm{O}) ; 133.45(\mathrm{CH}-\mathrm{O}) ; 123.18$ $\left(\mathrm{C}=C-\mathrm{N}_{\text {triazole }}\right) ; 122.89(\mathrm{CH}=\mathrm{C}) ; 81.65\left(\mathrm{CH}_{3}-\mathrm{N}\right) ; 71.90\left(\mathrm{CH}_{2}-\mathrm{O}-\right.$ $\left.\mathrm{CH}_{3}\right) ; 70.53\left(-\mathrm{CH}_{2}-\mathrm{O}\right) ; 69.41\left(\mathrm{~N}_{\text {triazole }}-\mathrm{CH}_{2}-\mathrm{CH}_{2}-\mathrm{O}\right) ; 58.99$ $\left(\mathrm{CH}_{3}-\mathrm{O}\right) ; 53.44\left(\mathrm{P}(\mathrm{O}) \mathrm{O}-\mathrm{CH}_{3}\right) ; 52.56(\mathrm{CHP}) ; 50.23\left(\mathrm{~N}_{\text {triazole }}-\mathrm{CH}_{2}{ }^{-}\right.$ $\left.\mathrm{CH}_{2}-\mathrm{O}\right) ; 48.51(\mathrm{CHC}=\mathrm{O}) ; 42.88\left(\mathrm{~N}-\mathrm{CH}_{2}\right) .{ }^{31} \mathrm{P}$ NMR $\left(\mathrm{CDCl}_{3}\right.$, $161.96 \mathrm{MHz}), \delta$ (ppm): 24.43; 24.38; 23.35; 23.19. FT-IR $\left(\nu \mathrm{cm}^{-1}\right): 2892\left(\nu_{\mathrm{C}-\mathrm{H}}\right) ; 1700\left(\nu_{\mathrm{C}=\mathrm{O}}\right) ; 1468\left(\nu_{\mathrm{C}=\mathrm{C} \text { triazole }}\right) ; 1241$ $\left(\nu_{\mathrm{P}=\mathrm{O}}\right)$.

Dimethylphosphonate-terminated oxanorbornene-functionalized PEO monomethyl ether $7 \mathbf{c}$. [N-Methylmaleimide]/[5c] = 20 (Table 1, run 9); conv.: 50\%. ${ }^{1} \mathrm{H}$ NMR $\left(\mathrm{CDCl}_{3}, 400 \mathrm{MHz}\right), \delta$ (ppm): $7.63\left(\mathrm{~s}, 1 \mathrm{H}\right.$, triazole); $6.40\left(\mathrm{t}, J=6.72 \mathrm{~Hz}, 1 \mathrm{H}, \mathrm{C}\left(\mathrm{CH}_{3}\right)-\right.$ $\mathrm{CH}=\mathrm{C}) ; 6.11\left(\mathrm{t}, J=6.72 \mathrm{~Hz}, 1 \mathrm{H}, \mathrm{CH}=\mathrm{CH}-\mathrm{C}\left(\mathrm{CH}_{3}\right)\right) ; 4.53(\mathrm{t}, J=$ 
Table 3 Conversion of the rDA reaction with $\mathbf{7 b}$ and $\mathbf{8 b}$ at different temperatures and solvents

\begin{tabular}{|c|c|c|c|c|c|}
\hline Run & $\begin{array}{l}\text { Oxanorbornene- } \\
\text { functionalized- } \\
\text { PEO }\end{array}$ & Solvent & $\begin{array}{l}\text { Temperature } \\
\left({ }^{\circ} \mathrm{C}\right)\end{array}$ & $\begin{array}{l}\text { Reaction } \\
\text { time }(\mathrm{h})\end{array}$ & $\begin{array}{l}\text { Conv. }{ }^{a} \\
(\%)\end{array}$ \\
\hline 1 & $7 \mathbf{b}$ & DMSO-d 6 & 110 & $12^{b}$ & 86 \\
\hline 2 & $7 \mathbf{b}$ & TCE- $\mathrm{d}_{2}$ & 110 & $12^{b}$ & 90 \\
\hline 3 & $8 b$ & DMSO- $\mathrm{d}_{6}$ & 110 & $1^{c}$ & - \\
\hline 4 & $8 b$ & DMSO- $_{6}$ & 80 & 24 & 30 \\
\hline 5 & $8 b$ & TCE- $\mathrm{d}_{2}$ & 110 & $6^{b}$ & 94 \\
\hline 6 & $8 b$ & $\mathrm{D}_{2} \mathrm{O}$ & 80 & 48 & 71 \\
\hline
\end{tabular}

${ }^{a}$ Determined by ${ }^{1} \mathrm{H}$ NMR spectroscopy by comparing the peak areas of the $\mathrm{CH}-\mathrm{O}$ groups of oxanorbornene at $\delta=5.13-5.39 \mathrm{ppm}$ and the methylene protons of the PEO in $\alpha$ of the triazole ring at $\delta=4.52 \mathrm{ppm}$. ${ }^{b}$ Degradation of the product in case of a longer reaction time. ${ }^{c}$ Degradation of the product.

$\left.8.66 \mathrm{~Hz}, 2 \mathrm{H}, \mathrm{N}_{\text {triazole }}-\mathrm{CH}_{2}-\mathrm{CH}_{2}-\mathrm{O}\right) ; 4.16(\mathrm{~d}, J=15.60 \mathrm{~Hz}, 1 \mathrm{H}$, $\mathrm{CHP}) ; 3.95$ (t, $\left.J=13.56 \mathrm{~Hz}, 2 \mathrm{H}, \mathrm{N}_{\text {triazole }}-\mathrm{CH}_{2}-\mathrm{CH}_{2}-\mathrm{O}\right) ; 3.86(\mathrm{~m}$, $\left.6 \mathrm{H}, \mathrm{P}(\mathrm{O}) \mathrm{O}-\mathrm{CH}_{3}\right) ; 3.84-3.51\left(\mathrm{~m}, 172 \mathrm{H}, \mathrm{CH}_{2}-\mathrm{CH}_{2}-\mathrm{O}\right) ; 3.46(\mathrm{t}, \mathrm{J}=$ $\left.6.24 \mathrm{~Hz}, 2 \mathrm{H}, \mathrm{NH}-\mathrm{CH}_{2}\right) ; 3.38\left(\mathrm{~s}, 3 \mathrm{H}, \mathrm{O}-\mathrm{CH}_{3}\right) ; 3.12-2.95(\mathrm{~m}, 2 \mathrm{H}$, $\mathrm{CH}-\mathrm{C}=\mathrm{O}) ; 2.79\left(\mathrm{~s}, 3 \mathrm{H}, \mathrm{CH}_{3}-\mathrm{N}\right) ; 2.31\left(\mathrm{~s}, 3 \mathrm{H}, \mathrm{C}(\mathrm{O}) \mathrm{CH}_{3}\right) ; 2.18(\mathrm{~s}$, $1 \mathrm{H}, \mathrm{NH}) .{ }^{31} \mathrm{P}$ NMR $\left(\mathrm{CDCl}_{3}, 161.96 \mathrm{MHz}\right), \delta(\mathrm{ppm}): 28.20 ; 26.98$; $25.78 ; 24.48$.

Phosphonic acid-terminated oxanorbornene-functionalized PEO monomethyl ether 8b. [N-Methylmaleimide $] /[6 \mathbf{b}]=20$ (Table 3, run 5); conv.: 94\%. ${ }^{1} \mathrm{H}$ NMR (DMSO-d $6,400 \mathrm{MHz}$ ), $\delta(\mathrm{ppm}): 8.23(\mathrm{~s}, 1 \mathrm{H}$, triazole); $6.73(\mathrm{~s}, 1 \mathrm{H}, \mathrm{CH}=\mathrm{C}) ; 5.22(\mathrm{~m}$, $2 \mathrm{H}, \mathrm{CH}-\mathrm{O}) ; 4.58$ (t, $\left.J=5.25 \mathrm{~Hz}, 2 \mathrm{H}, \mathrm{N}_{\text {triazole }}-\mathrm{CH}_{2}-\mathrm{CH}_{2}-\mathrm{O}\right) ; 4.38$ $(\mathrm{m}, 1 \mathrm{H}, \mathrm{CHP}) ; 3.84\left(\mathrm{t}, J=5.98 \mathrm{~Hz}, 2 \mathrm{H}, \mathrm{N}_{\text {triazole }}-\mathrm{CH}_{2}-\mathrm{CH}_{2}-\mathrm{O}\right)$; $3.77-3.36\left(\mathrm{~m}, 172 \mathrm{H}, \mathrm{CH}_{2}-\mathrm{CH}_{2}-\mathrm{O}\right) ; 3.35(\mathrm{t}, J=5.38 \mathrm{~Hz}, 2 \mathrm{H}, \mathrm{NH}-$ $\left.\mathrm{CH}_{2}\right) ; 3.24\left(\mathrm{~s}, 3 \mathrm{H}, \mathrm{O}-\mathrm{CH}_{3}\right) ; 3.05(\mathrm{~m}, 2 \mathrm{H}, \mathrm{CHC}=\mathrm{O}) ; 2.86(\mathrm{~s}, 3 \mathrm{H}$, $\left.\mathrm{CH}_{3}-\mathrm{N}\right) ; 2.51$ (s, $\left.1 \mathrm{H}, \mathrm{NH}\right) .{ }^{31} \mathrm{P}$ NMR (DMSO-d 6 , $161.96 \mathrm{MHz}$ ), $\delta$ (ppm): 10.96; 10.00; 9.77; 9.06. FT-IR $\left(\nu \mathrm{cm}^{-1}\right): 3368\left(\nu_{\mathrm{OH}}\right)$; $2881\left(\nu_{\mathrm{C}-\mathrm{H}}\right) ; 1698\left(\nu_{\mathrm{C}=\mathrm{O}}\right) ; 1656\left(\nu_{\mathrm{C}=\mathrm{C}}\right) ; 1466\left(\nu_{\mathrm{C}=\mathrm{C} \text { triazole }}\right) ; 1241$ $\left(\nu_{\mathrm{P}=\mathrm{O}}\right)$.

\section{General procedure of the retro Diels-Alder reaction from dimethylphosphonate-terminated oxanorbornene-} functionalized PEO monomethyl ether $7 \mathrm{~b}$ or phosphonic acidterminated oxanorbornene-functionalized PEO monomethyl ether $8 b$

Dimethylphosphonate-terminated or phosphonic acid-terminated oxanorbornene-functionalized PEO derivatives $\mathbf{7 b}$ and 8b $(0.05 \mathrm{~g} ; 0.0225 \mathrm{mmol})$ was introduced in a NMR tube. The reaction mixture was subsequently dissolved in $0.4 \mathrm{~mL}$ of deuterated solvent: DMSO- $\mathrm{d}_{6}, \mathrm{D}_{2} \mathrm{O}$ or 1,1,2,2-tetrachloroethane $\left(\right.$ TCE- $\left.\mathrm{d}_{2}\right)$. When a homogeneous solution was obtained, the NMR tube was immersed in an oil bath preset at 80 or $110{ }^{\circ} \mathrm{C}$ to allow the reaction to proceed (initial reaction time, $t=0$ ). NMR spectra were carried out periodically to monitor the conversion using ${ }^{1} \mathrm{H}$ NMR spectroscopy by comparing the peaks areas of the bridgehead protons of the oxanorbornene cycloadduct at $\delta=5.13-5.39 \mathrm{ppm}$ and the methylene protons linked to the triazole ring at $\delta=4.52 \mathrm{ppm}$.

\section{Results and discussion}

\section{Synthesis of phosphonated furan-functionalized PEO} monomethyl ethers

A series of dimethylphosphonate and phosphonic acid-terminated furan-functionalized poly(ethylene oxide) (PEO) monomethyl ethers (5a-c and $\mathbf{6 a}-\mathbf{b}$, respectively) was synthesized according to a strategy we have previously developed, ${ }^{22,23}$ combining the click CuAAC ${ }^{3}$ and the Kabachnik-Fields ${ }^{24-27}$ reactions (Scheme 2). The detailed procedure is described in the ESI. $\dagger$ Briefly, the Schiff base (2a-c), issued from reaction between aldehyde (1a-c) and $N$-propargylamine was reacted with dimethyl hydrogenophosphonate to afford the expected $\alpha$-aminophosphonate $(\mathbf{3 a} \mathbf{a}-\mathbf{c})$. The aminophosphonate was then engaged in a typical click coupling reaction with azidoterminated PEO monomethyl ether 2000 to afford the dimethylphosphonate-terminated furan-functionalized PEO monomethyl ether (5a-c), which was subsequently converted into the phosphonic acid homologue $(\mathbf{6 a - b})$ by dealkylation. All the structures were confirmed by Fourier transform-infra red (FT-IR), ${ }^{1} \mathrm{H},{ }^{13} \mathrm{C},{ }^{31} \mathrm{P}$ nuclear magnetic resonance (NMR) spectroscopy, and mass spectrometry (see ESI $\dagger$ ).

\section{Reactivity of the furan functionality in DA reaction}

The suitability of dimethylphosphonate-terminated furanfunctionalized PEO monomethyl ethers (5a-c) and the phosphonic acid homologue (6b) for the DA reaction was investigated using $\mathrm{N}$-methylmaleimide as the dienophile according to Scheme 3.

When $\mathbf{5 a - b}$ were heated in deuterated chloroform $\left(\mathrm{CDCl}_{3}\right)$ at $40{ }^{\circ} \mathrm{C}$ for 5 days with a $[N$-methylmaleimide $] /[5 \mathbf{a}-\mathbf{b}]$ molar ratio of 1 to 5 (runs $1-4$, Table 1 ), only minimal amounts, up to $13 \%$, could be detected using the typical peaks of the $\mathrm{CH}-\mathrm{O}$ groups of oxanorbornene at $\delta=5.13-5.39 \mathrm{ppm}$. However, when $[N$-methylmaleimide $] /[\mathbf{5 a}-\mathbf{b}]$ molar ratio was increased to 20 , conversion increased up to $82 \%$ (run 6, Table 1). Furthermore, when $\mathrm{N}, \mathrm{N}$-dimethylformamide (DMF) was used as the solvent, a near complete conversion to the oxanorbornene adduct was observed from 5b (run 8, Table 1). Moreover, comparative experiments in DMF show the remarkable influence of the furan group according to the position of the substitution (2-substituted one 5a vs. 3-substituted one 5b) and the presence of a methyl group (5c, from commercially available 5-methyl-2-furaldehyde). Indeed, the order of reactivity with respect to DA reaction was observed as: 3-substituted furan $\mathbf{5 b}$ $>$ 2,5-disubstituted furan $\mathbf{5 c}>2$-substituted furan $\mathbf{5 a}$ (runs 7-9,

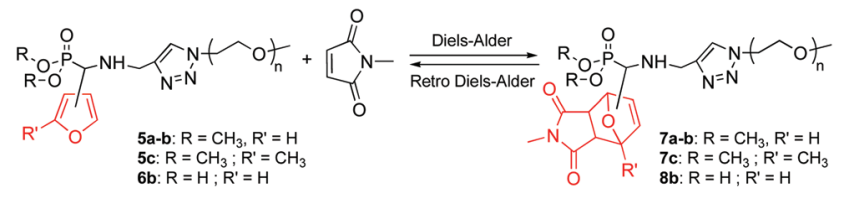

Scheme 3 DA and rDA reactions between furan-functionalized PEO monomethyl ethers and $\mathrm{N}$-methylmaleimide. 
Table 1). It seems that the furan side chain can have steric effects that may impact the progress of the reaction. In order for the DA reaction to occur, the furan moiety must be able to form a bridgehead; thus the rigidity of 2-substituted furan versus 3-substituted furan may also contribute to reduce the reactivity. ${ }^{33}$ The positive influence of the methyl group in 5 -position of the 2-substituted furan relative to the non-substituted one can be attributed to the electron-donating inductive effect of the methyl group as it is well-known that DA cycloadditions involving electron-rich dienes and electron-poor dienophiles proceed more favorably. ${ }^{34}$

The effect of solvent media on the conversion of the DA reaction has been examined. The reaction between $\mathbf{5 b}$ and $N$-methylmaleimide in deuterated solvents $\left(\mathrm{CDCl}_{3}, \mathrm{DMSO}-\mathrm{d}_{6}\right.$, $\mathrm{D}_{2} \mathrm{O}$ ) at 25 and $40{ }^{\circ} \mathrm{C}$ has been monitored using ${ }^{1} \mathrm{H}$ NMR spectroscopy. For example, Fig. 1 shows an overlay of ${ }^{1} \mathrm{H}$ NMR spectra of the reaction mixture of $\mathbf{5 b}$ and $N$-methylmaleimide in $\mathrm{D}_{2} \mathrm{O}$ at $40{ }^{\circ} \mathrm{C}$ at different intervals. Progress of the reaction is indicated by the disappearance of the signal of $\mathrm{CH}$ groups linked to the oxygen in the furan ring at $\delta=7.40-7.60 \mathrm{ppm}$ (labeled b \& c in Fig. 1) and the concomitant appearance of the signal of the bridgehead protons of the oxanorbornene cycloadduct at $\delta=5.00-5.50 \mathrm{ppm}$ (labeled $\mathrm{b}^{\prime} \& \mathrm{c}^{\prime}$ in Fig. 1). The conversion of the DA reaction was calculated by comparing the integration areas of the $\mathrm{CH}_{3}$ end-group of $\mathrm{PEO}$ at $3.38 \mathrm{ppm}$ (labeled a in Fig. 1) and of $\mathrm{CH}$ groups linked to the oxygen in the furan ring at $\delta=7.40-7.60$ ppm (labeled b \& c in Fig. 1).

The series of NMR spectra obtained were then used to generate Fig. 2, which shows the conversion of the DA reaction according to the solvent and the temperature versus time. The data suggest that the reaction proceeds more efficiently in water (open and black triangles in Fig. 2, 89\% and 98\% conversion in $24 \mathrm{~h}$ at $25{ }^{\circ} \mathrm{C}$ and $40{ }^{\circ} \mathrm{C}$, respectively). Lower yields of the resulting dimethylphosphonate-terminated oxanorbornene-functionalized PEO monomethyl ether $\mathbf{7 b}$ were observed when less polar organic solvents, namely DMSO (open and black circles in Fig. 2, 46\% and $68 \%$ conversion in $24 \mathrm{~h}$ at $25{ }^{\circ} \mathrm{C}$ and $40{ }^{\circ} \mathrm{C}$, respectively) and chloroform (open and black squares in Fig. 2, 14\% and 59\% conversion in $24 \mathrm{~h}$ at $25{ }^{\circ} \mathrm{C}$ and $40^{\circ} \mathrm{C}$, respectively) were used.

The acceleration of the DA reaction in water solution is in accordance with previous studies involving non-polymeric cycloreactants $^{33,35-38}$ and can been ascribed to enforced hydrophobic interactions between the cycloreactants and hydrogenbonding interactions between the dipolarophile and the solvent, both stabilizing the transition state. ${ }^{37}$ The reactivity of the phosphonic acid homologue $\mathbf{6 b}$ showed a less pronounced water-induced acceleration as compared to that of $\mathbf{5 b}$ (run $3 v s$. 4 \& run 7 vs. 8, Table 2), probably due to the presence of the strong hydrophilic character of the phosphonic acid moiety near the diene, which restricts the stabilizing hydrophobic interactions with the dienophiles in the transition state.

The ${ }^{31} \mathrm{P}$ NMR spectra of the oxanorbornene-functionalized PEO monomethyl ether cycloadducts $7 \mathbf{b}$ (Fig. 3) and $\mathbf{8 b}$ (Fig. S9B in the ESI $\dagger$ ) indicated the presence of four diastereoisomers corresponding to the four possible DA cycloadducts
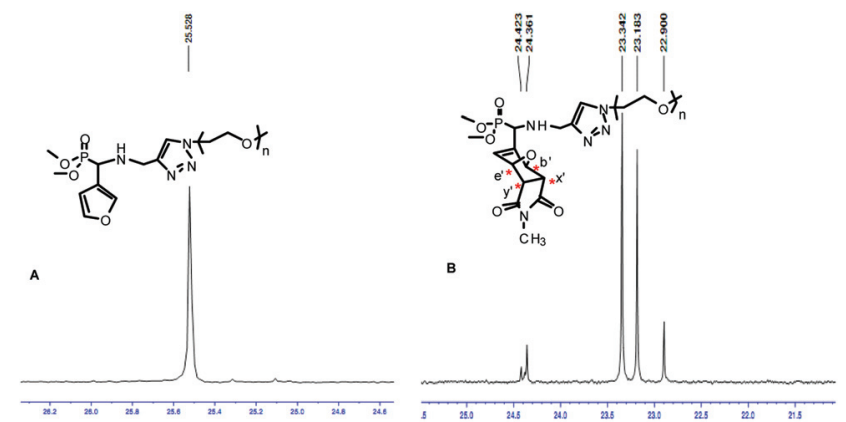

Fig. $3{ }^{1} \mathrm{H}$ decoupled ${ }^{31} \mathrm{P}$ NMR spectra of $(A) 6 b$ and (B) $7 b$; solvent: $\mathrm{CDCl}_{3}$.

resulting from the endo/exo and facial approaches, in a $53: 29: 12: 6$ ratio obtained from the peak integration area of the quantitative ${ }^{31} \mathrm{P}$ NMR spectrum of $7 \mathbf{b}$ (Fig. S10 in the ESI $\dagger$ ) acquired by a 1D sequence with inverse gated decoupling (zgig sequence that allows quantitative determination of the diastereoisomers ratios by suppression of nuclear overhauser effect). Based on the assumption that this thermal DA reaction is endo-selective (as commonly reported from related nonpolymeric reactants) and proceeds with low facial control in respect of the stereogenicity of the chiral (racemic) diene, ${ }^{39}$ the two major isomers detected on the ${ }^{31} \mathrm{P}$ NMR at $\delta=23.34$ and 23.18 ppm could be attributed to endo isomers. On the statement of an overall (global) endo selectivity better than 4 to 1 , and within the context of dynamic covalent chemistry, it should be noted that the predominant formation of the endo isomers is of particular interest since it has been shown that the rDA of endo DA-adducts most often takes place at 20-30 K lower temperatures than that of the corresponding exo DA-adducts. ${ }^{40}$

\section{Retro Diels-Alder reaction}

DA reactions can be reversed, via the retro-DA (rDA) reaction, typically at temperatures above $120^{\circ} \mathrm{C}$ resulting in the original diene and the dienophile. ${ }^{41,42}$ The feasibility of the rDA reaction was investigated with $\mathbf{7 b}$ and $\mathbf{8 b}$ in different solvents (Table 3). The rDA reaction was followed by ${ }^{1} \mathrm{H}$ NMR spectroscopy by comparing the peak areas of the $\mathrm{CH}-\mathrm{O}$ groups of oxanorbornene at $\delta=5.13-5.39 \mathrm{ppm}$ and the methylene protons of the PEO in $\alpha$ of the triazole ring at $\delta=4.52 \mathrm{ppm}$. A typical experiment is shown in Fig. 4, where the initial spectrum shows the oxanorbornene cycloadduct $7 \mathbf{b}$ in DMSO- $_{6}$ (see Fig. S11 in the ESI $\uparrow$ for the oxanorbornene cycloadduct 8b). The middle and third spectra show the situation reached at $110{ }^{\circ} \mathrm{C}$ after $1 \mathrm{~h}$ and $4 \mathrm{~h}$, corresponding to $41 \%$ and $73 \%$ conversion, respectively. The rDA reaction of the dimethylphosphonate-terminated oxanorbornene-functionalized PEO monomethyl ether $\mathbf{7 b}$ proceeded in a quasi-quantitative way at $110{ }^{\circ} \mathrm{C}$ within $12 \mathrm{~h}$ in both organic solvents DMSO-d $\mathrm{d}_{6}$ and deuterated 1,1,2,2-tetrachloroethane $\left(\mathrm{TCE}-\mathrm{d}_{2}\right)$ tested (runs 1 \& 2 , Table 3), indicating no influence of the polarity of the organic solvent. ${ }^{43}$ Similar results were obtained with the phos- 


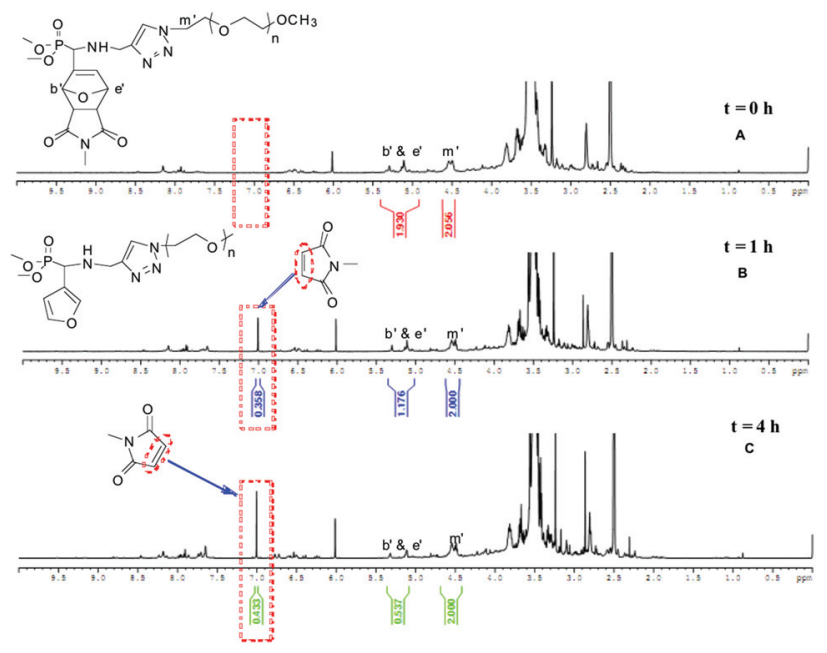

Fig. $4{ }^{1} \mathrm{H}$ NMR spectra of the rDA reaction of $7 \mathrm{~b}$ in DMSO- $\mathrm{d}_{6}$ at $110{ }^{\circ} \mathrm{C}$ for (A) $t=0 \mathrm{~h}$, (B) $t=1 \mathrm{~h}$ et (C) $t=4 \mathrm{~h}$.

phonic acid-terminated oxanorbornene-functionalized PEO monomethyl ether $\mathbf{8 b}$ for the rDA reaction carried out in TCE$\mathrm{d}_{2}$ (run 5, Table 3). When DMSO- $\mathrm{d}_{6}$ was used as the solvent (runs $3 \& 4$, Table 3), the reaction had to be performed at $80^{\circ} \mathrm{C}$ instead of $110^{\circ} \mathrm{C}$ to prevent the degradation of $\mathbf{8 b}$, resulting in a decrease of the conversion, as the temperature is not high enough to shift heavily the equilibrium of the reversible DA reaction to the predominant reversion to the precursors. ${ }^{41}$ Unlike what is observed with TCE- $\mathrm{d}_{2}$ and DMSO- $\mathrm{d}_{6}$ at $110{ }^{\circ} \mathrm{C}$ (runs $3 \& 5$, Table 3), the reaction carried out in $\mathrm{D}_{2} \mathrm{O}$ proceeded in $71 \%$ conversion at $80{ }^{\circ} \mathrm{C}$ after $48 \mathrm{~h}$ while preserving the integrity of the polymer (run 6, Table 3), allowing their utilization as controlled delivery systems in aqueous media.

\section{Conclusions}

The present work investigated the synthesis and the reactivity in the DA/rDA process of a series of novel phosphonated furan-functionalized PEO monomethyl ethers. Various dimethylphosphonate-terminated furan-functionalized PEO monomethyl ethers (5a-c) and their phosphonic acid-terminated homologues $(\mathbf{6 a}-\mathbf{b})$ have been successfully obtained using a combination of click CuAAC and Kabachnik-Fields reactions, starting from commercially available 2-furaldehyde, 3-furaldehyde, and 5-methyl-2-furaldehyde. Comparative experiments in DMF as the solvent have shown that the substitution of the furan diene greatly affects the reactivity during the DA reaction with $\mathrm{N}$-methylmaleimide, the 3 -substituted furan being the more reactive. The influence of the solvent on the DA/rDA process has shown that water facilitates both the DA and the rDA reactions, while maintaining the integrity of the polymer structure. These results have important implications in the area of controlled drug delivery systems and demonstrate that such phosphonated furan-functionalized POE have great potential in dynamic covalent applications, especially as thermolabile coatings for metallic nanoparticles.

\section{Acknowledgements}

We thank Emmanuelle Mebold, Patricia Gangnery, Amélie Durand, and Corentin Jacquemmoz for MALDI-TOF mass spectrometry, high resolution mass spectrometry (HR-MS), and ${ }^{1} \mathrm{H}$ nuclear magnetic resonance (NMR) analyses.

\section{Notes and references}

1 K. C. Nicolaou, S. A. Snyder, T. Montagnon and G. Vassilikogiannaki, Angew. Chem., Int. Ed., 2002, 41, 1668-1698.

2 J. A. Funel and S. Abele, Angew. Chem., Int. Ed., 2013, 52, 3822-3863.

3 H. C. Kolb, M. G. Finn and K. B. Sharpless, Angew. Chem., Int. Ed., 2001, 40, 2004-2021.

4 W. Xi, T. F. Scott, C. J. Kloxin and C. N. Bowman, Adv. Funct. Mater., 2014, 24, 2572-2590.

5 A. Gregory and M. H. Stenzel, Prog. Polym. Sci., 2012, 37, 38-105.

6 G. K. Such, A. P. R. Johnston, K. Liang and F. Caruso, Prog. Polym. Sci., 2012, 37, 985-1003.

7 A. S. Goldmann, M. Glassner, A. J. Inglis and C. BarnerKowollik, Macromol. Rapid Commun., 2013, 34, 810-849.

8 N. Zydziak, B. Yameen and C. Barner-Kowollik, Polym. Chem., 2013, 4, 4072-4086.

9 Y.-L. Liu and T.-W. Chuo, Polym. Chem., 2013, 4, 21942205.

10 M. A. Tasdelen, Polym. Chem., 2011, 2, 2133-2145.

11 A. Gandini, Polym. Chem., 2010, 1, 245-251.

12 A. Gandini, Prog. Polym. Sci., 2013, 38, 1-29.

13 D. Le, V. Montembault, J.-C. Soutif, M. Rutnakornpituk and L. Fontaine, Macromolecules, 2010, 43, 5611-5617.

14 G. Morandi, G. Mantovani, V. Montembault, D. M. Haddleton and L. Fontaine, New J. Chem., 2007, 31, 1826-1829.

15 V. Lapinte, L. Fontaine, V. Montembault, I. Campistron and D. Reyx, J. Mol. Catal. A: Chem., 2002, 190, 117-129.

16 M. King and A. Wagner, Bioconjugate Chem., 2014, 25, 825839.

17 W. Tang and M. L. Becker, Chem. Soc. Rev., 2014, 43, 70137039.

18 M. F. Debets, S. S. Van Berkel, J. Dommerholt, A. J. Dirks, F. P. J. T. Rutjes and F. L. Van Delft, Acc. Chem. Res., 2011, 44, 805-815.

19 J. M. Palomo, Eur. J. Org. Chem., 2010, 6303-6314.

20 A. Herrmann, Chem. Soc. Rev., 2014, 43, 1899-1933.

21 Y. Jin, Q. Wang, P. Taynton and W. Zhang, Acc. Chem. Res., 2014, 47, 1575-1586.

22 T. T. T. N'Guyen, H. T. T. Duong, J. Basuki, V. Montembault, S. Pascual, C. Guibert, J. Fresnais, 
C. Boyer, M. R. Whittaker, T. P. Davis and L. Fontaine, Angew. Chem., Int. Ed., 2013, 52, 14152-14156.

23 T. T. T. N'Guyen, K. Oussadi, V. Montembault and L. Fontaine, J. Polym. Sci., Part A: Polym. Chem., 2013, 51, 415-423.

24 M. I. Kabachnik and T. Y. Medved, Dokl. Akad. Nauk SSSR, 1952, 83, 689-692, (Chem. Abstr., 1953, 47, 2724b).

25 E. K. Fields, J. Am. Chem. Soc., 1952, 74, 1528-1531.

26 N. S. Zefirov and E. D. Matveeva, ARKIVOC, 2008, 1-17.

27 G. Keglevich and E. Balint, Molecules, 2012, 17, 1282112835.

28 L. Ménard, L. Fontaine and J.-C. Brosse, React. Polym., 1994, 23, 201-212.

29 R. Kakuchi and P. Theato, ACS Macro Lett., 2014, 3, 329-332.

30 Y. Zhang, Y. Zhao, B. Yang, C. Zhu, Y. Wei and L. Tao, Polym. Chem., 2014, 5, 1857-1862.

31 N. Illy, G. Couture, R. Auvergne, S. Caillol, G. David and B. Boutevin, RSC Adv., 2014, 4, 24042-24052.

32 C.-O. Turrin, A. Hameau and A.-M. Caminade, Synthesis, 2012, 1628-1630.
33 K. C. Koehler, A. Durackova, C. J. Kloxin and C. N. Bowman, AIChE J., 2012, 58, 3545-3552.

34 R. C. Boutelle and B. H. Northrop, J. Org. Chem., 2011, 76, 7994-8002.

35 D. C. Rideout and R. Breslow, J. Am. Chem. Soc., 1980, 102, 7816-7817.

36 R. Breslow, U. Maitra and D. Rideout, Tetrahedron Lett., 1983, 24, 1901-1904.

37 S. Otto and J. F. B. N. Engberts, Pure Appl. Chem., 2000, 72, 1365-1372, and references cited.

38 A. Lubineau and E. Meyer, Tetrahedron, 1988, 44, 60656070.

39 A. Whiting, Adv. Asymmetric. Synth., 1996, 126-145.

40 J. Canadell, H. Fischer, G. De With and R. A. T. M. Van Bethem, J. Polym. Sci., Part A: Polym. Chem., 2010, 48, 43456-43467.

41 H. Kwart and K. King, Chem. Rev., 1968, 68, 415-447.

42 B. Rickborn, Org. React., 1998, 52, 1-393.

43 H.-L. Wei, Z. Yang, H.-J. Chu, J. Zhu, Z.-C. Li and J.-S. Cui, Polymer, 2010, 51, 1694-1702. 